\title{
THE RESPONSE OF HUMAN TISSUES TO CARBON REINFORCED EPOXY RESIN
}

\author{
C. B. HOWARD, K. J. J. TAYTON, A. GIBBS \\ From Cardiff Royal Infirmary, Cardiff
}

\begin{abstract}
The tissue surrounding carbon fibre reinforced epoxy resin plates applied to forearm and tibial fractures was biopsied in 32 patients at the time the plates were removed. The reaction was minimal and was compared with that in a control group of 16 similar patients in whom stainless steel plates were used. No significant histological differences were found.

A series of experiments on rats, in which the histology was studied from 2 to 78 weeks, also showed that there was very little reaction to carbon fibre reinforced plastic.
\end{abstract}

In recent years carbon fibre reinforced plastics (CFRP) have been extensively employed in industry, their principal attraction being great strength associated with extreme lightness. Early in the 1980s it was shown that these materials had potential for use as plates in the fixation of fractures (Claes et al. 1980), and in 1982 successful results were reported of the first clinical trial using plates made from carbon fibre reinforced epoxy resin (Tayton et al. 1982).

The satisfactory acceptance of "pure" carbon fibre and of epoxy resin in human tissues had already been established (Debney 1971; Jenkins et al. 1977; Jenkins and McKibbin 1980), so it was not anticipated that any serious problems would be encountered from implanting a composite of the two. There are, however, a large variety of epoxy resins and, in unpolymerised forms, many rapidly cause allergic reactions in the skin of workers exposed to them. This does not appear to be a problem with the polymers, as several thousand cardiac pacemakers encased in epoxy resin have been inserted into patients and there have been only two or three reports of adverse reactions, all probably coincidental (Magilligan and Isshak 1980).

Nevertheless, as with any new material proposed for implantation, the tissue reactions need to be examined histologically, first in animals and then in human subjects. The results of our animal studies and of the first 32 consecutive human cases are reported in this paper.

C. B. Howard. FRCS. Lecturer in Orthopaedic and Traumatic Surgery A. Gibbs. FRCPath. Senior Lecturer in Pathology

Cardiff Royal Infirmary. Newport Road. Cardiff CF2 1SZ, Wales.

K. J. J. Tayton, FRCS, Consultant in Orthopaedic and Traumatic Surgery

Royal Gwent Hospital, Newport, Gwent NPT 2BU, Wales.

Requests for reprints should be sent to Mr K. J. J. Tayton.

( 1985 British Editorial Society of Bone and Joint Surgery $0301620 \times 854120 \$ 2.00$

\section{MATERIALS AND METHODS}

Studies in rats. A cuboid piece of CFRP measuring $5 \mathrm{~mm} \times 3 \mathrm{~mm} \times 3 \mathrm{~mm}$ was inserted into the left gluteal muscle in each of a series of 16 six-week-old Wistar rats. Pairs of rats were then killed at 2, 4, 6, 8, 12, 16, 26 and 78 weeks, respectively and the legs were fixed in formalin. After 14 days the CFRP was dissected out and the remaining tissue mounted in paraffin blocks.

Several sections were cut to include the space in which the CFRP had lain; half were stained with haematoxylin and eosin and the other half with Martius scarlet blue.

Studies in humans. A series of 32 human fractures which had been internally fixed with CFRP plates was also studied. The plates were left in situ for an average of 44 weeks on the tibia and 40 weeks on the forearm bones.

When the plates were removed, biopsies were taken from the overlying tissue, from around a screw-hole and from bone at the original fracture site. All the specimens were fixed in formalin and mounted in paraffin. All sections were stained with haematoxylin and eosin, and Martius scarlet blue. In addition some of the bone sections were stained by the tetrachrome and trichrome techniques.

A parallel series of 16 human fractures internally fixed with stainless steel plates also was studied, and similar biopsies taken and prepared as for the group fixed with CFRP plates.

Histological studies. Each slide was carefully examined by one of us (AG) and the presence of the following around the implant was recorded: fibrosis, mononuclear cells, giant cells, and polymorphs.

The sections were each graded on a scale from 0 to 3 as follows: Grade 0-no reaction; Grade 1 -an occasional scattered mononuclear cell, giant cell or neutrophil, or a very thin layer (no more than two cells thick) of granulation or fibrous tissue situated around the 
material: Grade 2-moderate numbers of mononuclear cells, giant cells, or neutrophils; granulation or fibrous tissue three to six cells thick situated around the material; Grade 3-numerous mononuclear cells, giant cells or neutrophils or a thick layer of granulation or fibrous tissue more than six cells thick surrounding the material.

\section{RESULTS}

As can be seen from Table I, apart from a fine layer of fibrous tissue encapsulating the implant, very little reaction was seen in any of the rats. In one rat killed at six weeks. a lymphoma was found in an axillary lymph node.

Table I. Histological findings in the pairs of rats examined at various times

$\begin{array}{lllll}\text { Weeks } & \text { Fibrosis } & \begin{array}{l}\text { Mononuclear } \\ \text { cells }\end{array} & \begin{array}{l}\text { Giant } \\ \text { cells }\end{array} & \text { Polymorphs } \\ 2 & 1 & 0 & 1 & 0 \\ 4 & 1 & 0 & 0 & 0 \\ 6 & 1 & 0 & 1 & 0 \\ 8 & 1 & 0 & 0 & 0 \\ 12 & 1 & 0 & 0 & 0 \\ 16 & 1 & 0 & 0 & 0 \\ 26 & 1 & 0 & 0 & 0 \\ 78 & 1 & 0 & 0 & 0\end{array}$

In the humans, the tissue reaction to steel and to CFRP was very similar (Table II). In both groups a thin fibrous membrane formed over the plate. In just over half of the group fixed with CFRP plates $(53 \%)$ and in just under half of the group fixed with stainless steel plates $(43 \%)$ there was some giant-cell reaction to the debris. In about two-third of both groups $(65 \%$ for the CFRP and $63 \%$ for the steel plates) a mononuclear cell reaction could be demonstrated (Figs 1 and 2).

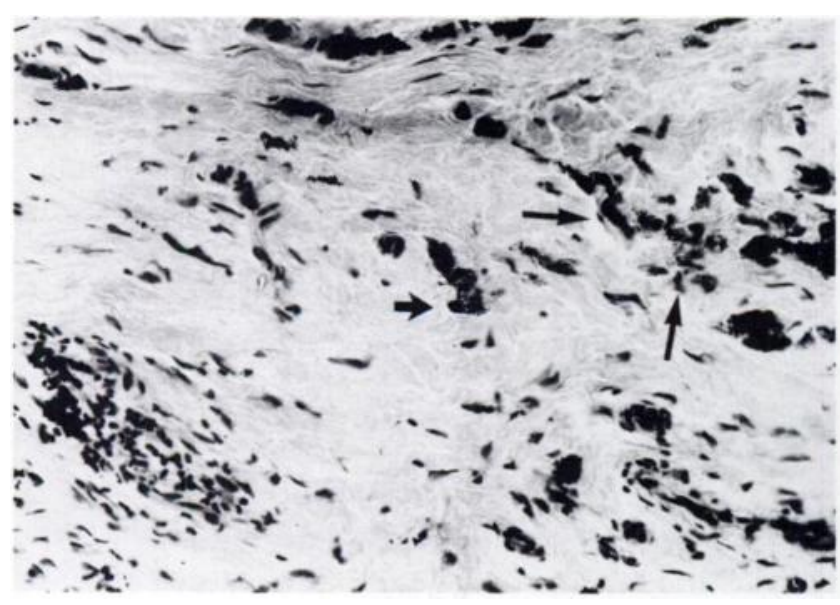

Fig. 1
Table II. Numbers of patients with either a CFRP plate or a stainless steel plate, showing the grades of the histological features examined

\begin{tabular}{|c|c|c|c|c|c|}
\hline \multirow[b]{2}{*}{ Feature } & \multirow[b]{2}{*}{ Grade } & \multicolumn{2}{|c|}{ CFRP plates } & \multicolumn{2}{|c|}{ Stainless steel plates } \\
\hline & & Number & $\%$ & Number & $\%$ \\
\hline \multirow[t]{4}{*}{ Fibrosis } & 0 & 0 & 0 & 0 & 0 \\
\hline & 1 & 30 & 94 & 15 & 94 \\
\hline & 2 & 2 & 6 & 1 & 6 \\
\hline & 3 & 0 & 0 & 0 & 0 \\
\hline \multirow[t]{4}{*}{ Giant cells } & 0 & 15 & 47 & 9 & 57 \\
\hline & 1 & 13 & 41 & 4 & 25 \\
\hline & 2 & 3 & 9 & 1 & 6 \\
\hline & 3 & 1 & 3 & 2 & 12 \\
\hline \multirow[t]{4}{*}{ Mononuclear cells } & 0 & 11 & 34 & 6 & 38 \\
\hline & 1 & 15 & 47 & 6 & 38 \\
\hline & 2 & 3 & 9 & 3 & 19 \\
\hline & 3 & 3 & 9 & 1 & 6 \\
\hline \multirow[t]{4}{*}{ Polymorphs } & 0 & 32 & 100 & 16 & 100 \\
\hline & 1 & 0 & 0 & 0 & 0 \\
\hline & 2 & 0 & 0 & 0 & 0 \\
\hline & 3 & 0 & () & 0 & 0 \\
\hline
\end{tabular}

Around the screw-holes there was a variable amount of staining which was particularly noticeable when CFRP plates had been used (Fig. 3).

\section{DISCUSSION}

As can be seen clearly from our results, there was little reaction to CFRP in rats. Other workers investigating tissue reaction to various plastics have observed that an "intimal layer" formed around this type of implant in

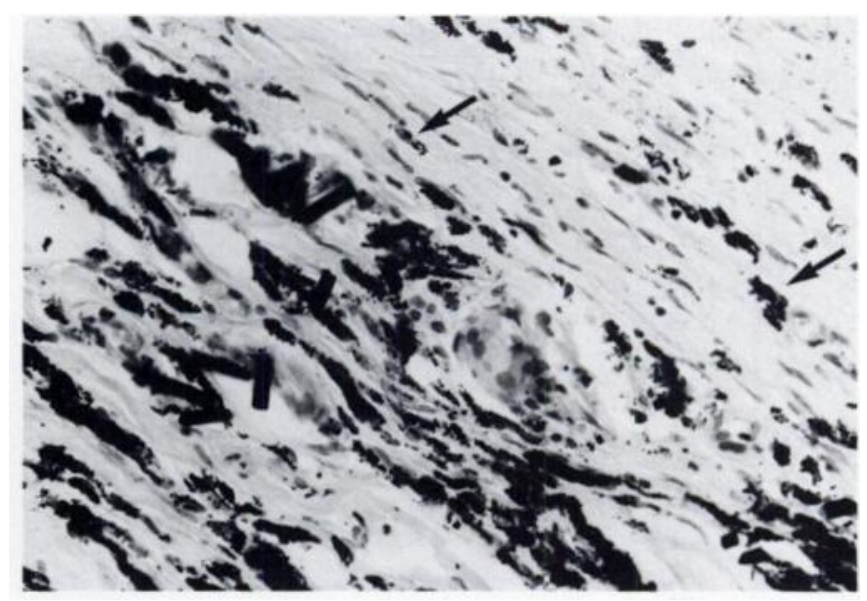

Fig. 2

Figure 1-Human tissue from around a stainless steel plate. The connective tissue is relatively bland, apart from small focal collections of lymphocytes and plasma cells. Small particles of metallic debris can be seen (arrows). (Haematoxylin and eosin, $\times 250$.) Figure $2-$ Human tissue from around a CFRP plate. Large carbon fibres are present eliciting a mild giant-cell response, and small carbon particles are also seen (arrows) lying within macrophages (haematoxylin and eosin, $\times 250$ ). 
rats (Oppenheimer et al. 1955, 1958), and we found similarly with our epoxy resin that very little else was induced. Indeed, the very inert nature of CFRP implants was most encouraging.

Although the number of animals in our study was small, primarily because early tissue reactions were being investigated, it appeared that the responses were all similarly slight and that they did not noticeably progress with time. The single lymphoma found in a rat killed at six weeks lends justification for continued observation of clinical cases but, by itself, gives no cause for alarm, as rats are notoriously prone to develop tumours in response to materials which are well tolerated in humans (Oppenheimer et al. 1955; Heath, Freeman and Swanson 1971).

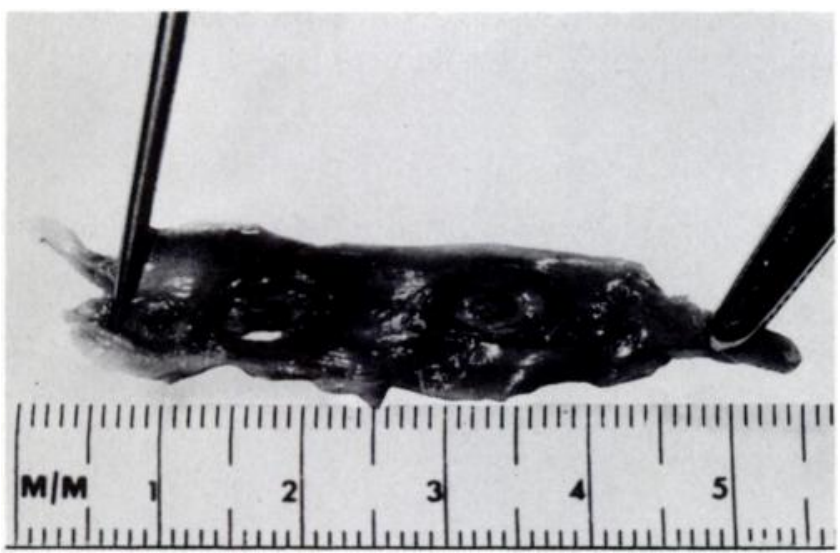

Fig. 3

The membrane overlying a tibial CFRP plate showing the staining particularly concentrated around the screw-holes.

The human study has produced a more complicated picture; to some extent this is due to the limited quantity of material available from human biopsy. Direct comparison with the results in the rats was extremely difficult, and it was felt that more would be gained by comparing biopsy material from two groups of human subjects: one group had received stainless steel implants, which have long been recognised as safe and hence would be suitable as controls for those who had received CFRP implants.

Detailed examination of this biopsy material revealed that in both groups the tissue reactions were very similar, and that no serious adverse reaction was present in any of the specimens (Figs 1 and 2). Indeed CFRP seemed to be tolerated just as well as stainless steel.

In both sets of material debris from the implant was noted and this was concentrated around the screw-holes. In the group with CFRP implants this was more severe, and fairly marked tissue staining was seen due to carbon deposition (Fig. 3). Although this did not appear to have any clinical significance, it implies that tattoo-staining of the skin might occur, and further development is in progress to try to eliminate this.

In conclusion, the results from both animal and human studies are very encouraging and give no cause for concern regarding the continued use of carbon fibre reinforced epoxy resin as an implant material.

\section{REFERENCES}

Claes L, Burri C, Kinzl L, Fitzer E, Hüttner W. Less rigid fixation with carbon fibre-reinforced materials: mechanical characteristics and behaviour in vivo. In: Uhthoff HK, Stahl E, eds. Current concepts of internal fixation of fractures. Berlin etc: Springer-Verlag, 1980:156-9.

Debney DJ. Cardiac pacemaker encapsulation investigation. Biomed Eng 1971;6:458-62, 472 .

Heath JC, Freeman MAR, Swanson SAV. Carcinogenic properties of wear particles from prostheses made in cobalt-chromium alloy. Lancet 1971 ; i:564-6.

Jenkins DHR, Forster IW, McKibbin B, Rális ZA. Induction of tendon and ligament formation by carbon implants. J Bone Joint Surg [Br] 1977;59-B:53-7.

Jenkins DHR, McKibbin B. The role of flexible carbon-fibre implants as tendon and ligament substitutes in clinical practice: a preliminary report. J Bone Joint Surg [Br] 1980;62-B:497-9.

Magilligan DJ Jr, Isshak G. Carcinoma of the breast in a pacemaker pocket; simple recurrence or oncotaxis? Pace 1980;3:220-3.

Oppenheimer BS, Oppenheimer ET, Danishefsky I, Stout AP, Eirich FR. Further studies of polymers as carcinogenic agents in animals. Cancer Res 1955;15:333-40.

Oppenheimer BS, Oppenheimer ET, Stout AP, Willhite M, Danishefsky I. The latent period in carcinogenesis by plastic in rats and its relation to the presarcomatous stage. Cancer 1958;11:204-13.

Tayton K, Johnson-Nurse C, McKibbin B, Bradley J, Hastings G. The use of semi-rigid carbon-fibre reinforced plastic plates for the fixation of human fractures: results of preliminary trials. $J$ Bone Joint Surg [Br] 1982;64-B: 105-11. 